\title{
What are the Specifics of Abdominal Wall Surgery in Cirrhotic Patients
}

\author{
David Moszkowicz', Marc-Antoine Allard², Marius Anastasiu ${ }^{3}$ \\ 1Department of Digestive Surgery, Louis-Mourier Hospital, DMU ESPRIT - GHU AP-HP. Nord, University of Paris, France \\ ${ }^{2}$ Department of Surgery, Paul-Brousse Hospital, Assistance Publique Hôpitaux de Paris (APHP), Centre Hépato-Biliaire, \\ Villejuif, France, Département Hospitalo-Universitaire Hepatinov, Villejuif, France; INSERM, Unit 1193, Villejuif, France \\ ${ }^{3}$ General Surgery Department, County Hospital Buzau, Romania
}

Corresponding author:

David Moszkowicz, MD, PhD

Department of Digestive Surgery,

Louis-Mourier Hospital

DMU ESPRIT - GHU AP-HP. Nord

University of Paris, France

178 Rue des Renouillers 92700

Colombes, France

E-mail: david.moszkowicz@aphp.fr

\section{Rezumat}

Care sunt specificațiile chirurgiei parietale la pacienții cirotici

Riscul de a dezvolta o hernie a peretelui abdominal este ridicat la pacientul cirotic, din cauza asocierii ascitei, hipoalbuminemiei şi amiotrofiei cu subnutriția prezentă în mod frecvent în ciroză. Astfel, aproape $20 \%$ dintre pacienții cirotici dezvoltă o hernie ombilicală. Intervenția chirurgicală parietală este cea mai riscantă la pacientul cirotic iar indicațiile acesteia trebuie discutate de la caz la caz. Obiectivul acestui studiu a fost de a trece în revistă întreaga literatură chirurgicală parietală pentru a defini în mod cât mai adecvat indicațiile chirurgicale şi specificul managementului lor terapeutic. Cercetarea se bazează pe publicațiile din Pubmed si Google Scholar în perioada ianuarie 1995 - decembrie 2019, folosind limba franceză şi engleză ca limbi de publicare. Cuvintele cheie folosite sunt „hernia” (plasa) şi „,iroză hepatică”. In anumite situații se recomandă controlul preoperator al ascitei. Chiar şi în cazul ascitei neinfectate se poate folosi o proteză parietală, de preferință în poziția retromusculară. Având în vedere riscul de hemoragie, se recomandă utilizarea cu prudență a laparoscopiei. De asemenea, nu am obținut destule date pentru a putea recomanda introducerea unui şunt porto-sistemic pe cale transjugulară sau utilizarea unei pompe peritoneo-vezicale pentru a reduce volumul de ascită înainte de intervenția parietală la pacienții cirotici.

Cuvinte cheie: ciroză, tratarea herniei, hernie inghinală, mortalitate, intervenție chirurgicală 


\begin{abstract}
The risk of developing an abdominal wall hernia is high in the cirrhotic patient, due to the association of ascites, hypoalbuminemia and amyotrophy in connection with undernutrition frequently associated with cirrhosis. Thus, almost $20 \%$ of cirrhotic patients develop an umbilical hernia. Parietal surgery is more at risk in cirrhotic patients and its indications must be discussed on a case-by-case basis. The objective of this work was to review the entire literature on wall surgery in order to best define the surgical indications and the specifics of their management. The bibliographic research was done on Pubmed® over the period from January 1995 to December 2019, using French and English as publication languages. The keywords retained were "hernia" [Mesh] and "liver cirrhosis" [Mesh]. In an elective situation, preoperative ascites control is recommended. A parietal prosthesis can be used, even in the case of uninfected ascites, preferably in the retromuscular position. Laparoscopy should be used with caution, due to the bleeding risk. No recommendation can be made on the use of prophylactic intra-abdominal drainage. The literature data do not allow the trans-jugular route portosystemic shunt recommendation, nor the use of a peritoneal-vesical pump to decrease the volume of ascites before parietal surgery in cirrhotic patients.
\end{abstract}

Key words: cirrhosis, hernia repair, incisional hernia, mortality, surgery

\section{Introduction}

The risk of developing an abdominal wall hernia is high in the cirrhotic patient, due to the association of ascites, hypoalbuminemia and amyotrophy in connection with undernutrition frequently associated with cirrhosis (1). Thus, almost $20 \%$ of cirrhotic patients develop an umbilical hernia (2). This risk increases in the presence of ascites (3).

The presence of ascites also increases the risk of a complicated hernia (skin ulceration, navel rupture, strangulation) and the mortality risk (4). On the other hand, it is shown that the presence of cirrhosis increases the risk of mortality after abdominal wall surgery $(5,6)$.

Parietal complications raise issues specific to cirrhosis: elective indications, perioperative management of liver disease and ascites, technical modalities (place of laparoscopy and drainage). These points are the subject of these recommendations.

The objective of this work was to take stock of the state of knowledge on the management of hernias and incisionals hernia in cirrhotic patients.

\section{Material and Methods}

The bibliographic research was done on Pubmed $^{\circledR}$ over the period from January 1995 to December 2017, using French and English as the publication languages. The keywords retained were "hernia" (Mesh) and "liver cirrhosis" (Mesh). This research identified 195 articles in total. The PRISMA graph which summarizes the research methodology is presented in Fig. 1. We have excluded articles on non-adult populations whose subjects were not human. The search was extended with the Google Scholar $^{\circledR}$ tool, the references of the articles consulted, to retain a total of 26 articles (Table 1). No high-powered randomized controlled clinical trial has been found in the literature.

\section{Results: Clinical Practice Recommendations}

\section{Surgical Indications}

Surgical indications for abdominal wall hernias are symptomatic hernia and complicated hernia: strangulation, skin lesion, umbilicus rupture with ascites leakage. Strangulation occurs in the event of a sudden decrease in the 
Figure 1. PRISMA flow diagram
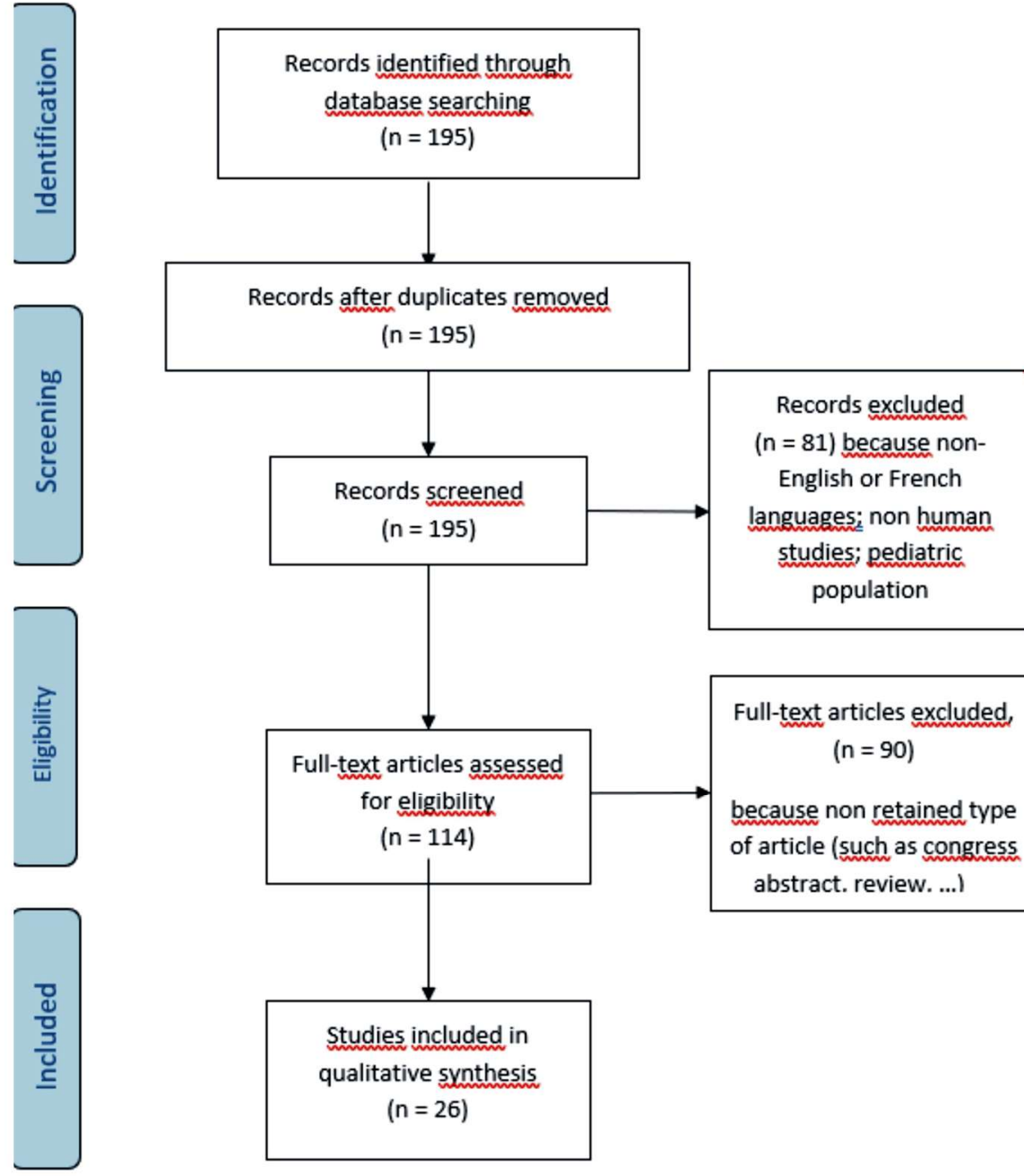

Full-text articles excluded

( $n=90)$

because non retained type

of article (such as congress

abstract. review. ...)

\begin{tabular}{lc}
\hline Level of Scientific Evidence Provided by the Literature & Number of Articles [ref] \\
\hline Level 1 & 0 \\
High-power randomized controlled trials & \\
Meta-analysis of randomized controlled trials & \\
Decision analysis based on well-conducted data & 4 \\
\hline Level 2 & $1[31]$ \\
Low-power randomized controlled trials & $1[12]$ \\
Well-conducted non-randomized comparative studies & $2[16,20]$ \\
Cohort studies & 0 \\
\hline Level 3 & 20 \\
Case-control study & $2[23,34]$ \\
\hline Level 4 & $20[4,5,6,9,10,11,13,14,15,17$, \\
Comparative studies with significant biases & $18,21,22,24,29,30,36,37,38,39]$ \\
Retrospective studies & 0 \\
& \\
Case series &
\end{tabular}

Table 1. Selected articles with level of evidence
Case series 
ascites volume due to an umbilicus rupture, an evacuative puncture, the medical treatment optimization or the placement of a TIPS (Transjugular Intrahepatic Portosystemic Shunt) (7).

\section{Treatment of Cirrhotic Umbilical Hernia}

In practice, the procedures performed most often include an omphalectomy (as the skin is poorly vascularized and injured), intraperitoneal drainage allowing the volume of postoperative ascites to be reduced to limit the tensioning of the parietal repair, raphia transverse musculo-aponeurotic with slowly absorbable points or the placement of a prosthesis avoiding the intra-peritoneal position (pre-peritoneal or retro-muscular), a continuous cutaneous overlock ("Canadian") to prevent leakage of liquid 'ascites $(2,8)$.

\section{Treatment of Inguino-Femoral Fernia of Cirrhotic Patients}

It has no specificity, in the absence of significant collateral venous circulation (9).

\section{Treatment of the Incisional Hernia in the Cirrhotic (except transplanted cirrhotic)}

To date, no study has specifically studied the problem of uncomplicated event therapy in cirrhotic patients.

In an elective situation, the morbidity rate after umbilical and inguinal hernia repair in cirrhotic patients without ascites but with preserved hepatic function appears comparable to those observed in non-cirrhotic patients $(6,10-12)$. This work demonstrates the feasibility of surgical treatment in selected and symptomatic cirrhotic patients.

The mortality risk factors after wall surgery in cirrhotic patients are the urgent nature of the intervention (mortality reaches $4 \%$ in emergency and $0.5 \%$ in scheduled surgery), a score for MELD (Model for Endstage Liver Disease) $>15$, hypoalbuminemia $(<30 \mathrm{~g} / \mathrm{l})$, Child C stage and refractory ascites $(4,12-15)$
In total, symptomatic hernia surgery in an elective situation (except emergency) in the cirrhotic patient with preserved function (MELD <15) and with controllable ascites is recommended. In patients with MELD > 15 and/or refractory ascites, elective surgical treatment cannot be recommended. The treatment of in the cirrhotic cannot be recommended, in the absence of acute complication, because of the lack of available data.

\section{Surgery Results}

\section{Short term}

The mortality from wall surgery (inguinal or umbilical hernia) is spontaneously higher in cirrhotic patients, evaluated at 5\% regardless of liver function (5). Similarly, cirrhotic patients have a higher morbidity and more use of postoperative intensive care (16). This mortality is higher in case of decompensated cirrhosis (Child C) and especially in case of emergency intervention, in particular due to the more frequent recourse to a digestive resection $(6,15,17)$. Indeed, the observed mortality after support Emergency hernia in cirrhotic patients varies between $2 \%$ and $10 \%$ against $1 \%$ when performed in elective conditions (6.14 to 19). In the national registry study by Carbonell et al., Emergency surgery was associated with 7 times higher mortality (3.8\% vs. $0.5 \% ; p<5 \%)(10)$. In the Gray et al. Registry study of 1,421 umbilical hernia cures, the existence of cirrhosis was an independent risk factor for postoperative morbidity in emergency surgery (OR 4.4; 95\% CI 1.3-14.3) (17).

Preexisting ascites is most often not in itself a risk factor for postoperative morbidity and mortality $(20,21)$. However, ascites is an independent risk factor for recurrence in retrospective series comparing simple raphia in the presence of uncontrolled ascites with raphia preceded by diversion by a peritonealvenous shunt (22-24), with a cumulative relative risk of recurrence of 8.5 in the metaanalysis of McKay et al. (25).

All in all, emergency surgery is the main 
factor of postoperative mortality in cirrhotic patients. Uncontrolled ascites is the main risk factor for recurrence after elective surgery.

\section{On the long-term}

The occurrence of a disruption after abdominal surgery can be postponed, with a maximum rate observed at 3 years (26). No data are available in the long-term cirrhotic population on rates of recurrence and chronic sepsis, although cirrhosis is not recognized as a risk factor for operative site infection in the VHWG classification (27).

The inguinal hernia treatment is associated with an improvement in the quality of life in cirrhotic patients, in particular at the Child C stage and / or in the presence of refractory ascites (12).

\section{Technical Features}

\section{Preoperative}

A recurrence rate of $73 \%$ has been reported when the repair is performed in the presence of ascites (28). Ascites is the main risk factor for recurrence after surgical treatment of a wall hernia in cirrhotic patients $(18,25)$. In a meta-analysis of non-randomized studies published in 2009, the presence of uncontrolled ascites was the main independent risk factor for recurrence ([RR] 8.5; 95\% CI [2.7-27]) (25).

In total, in an elective situation, the preoperative control of ascites is recommended.

\section{Intraoperative}

\section{Use of prosthesis}

The use of meshs in patients with ascites and without ascites has been reported by cohort studies or small case series. $(12,20,21,29,30)$. None of these studies have shown significant excess morbidity related to the use of a prosthesis.

An undeclared Egyptian randomized trial comparing 40 cirrhotic patients operated for a symptomatic or complicated umbilical hernia reported a comparable local infection rate with on the other hand a significant reduction in the rate of recurrence in the polypropylene prosthesis group (3\% in the prosthesis group vs. $14 \%$ in the raffia group; $p<0.05)(31)$.

In total, the available data support the use of prosthesis in the cirrhotic patient, even in the presence of uninfected ascites.

\section{Approach way: place of laparoscopy}

The place of laparoscopy in cirrhotic patients is classically discussed because of the haemorrhagic risk linked to portal hypertension, collateral venous circulation and thrombocytopenia (32).

Small retrospective and case series have reported the feasibility of repairing an umbilical or inguinal hernia in cirrhotic patients via the laparoscopic route with low morbidity $(29,33)$. In a recent retrospective study of the American registry (34), comparing wall surgery by direct approach and by laparoscopy, in emergency or in elective situation, in 3594 patients with chronic hepatopathy defined by a MELD score $\geq 9$, the laparoscopic route was associated with a lower rate of infection of the operating site $(0.23$, $95 \%$ CI $0.07-0.74 ; p=0.01)$, shorter hospital stays (3.7 vs. 5 days ) but at similar rates of systemic complications, haemorrhage, reoperation and readmission. These data were confirmed by a propensity score analysis. In the subgroup of 562 patients with ascites, 35 (6.2\%) underwent laparoscopic treatment and this approach was associated with higher mortality (OR 5.4, 95\% CI 1-28.6; p = 0.05), more systemic complications (OR 7, 95\% CI $2-24 ; \mathrm{p}=0.01$ ) and more reoperations than the direct approach (34).

In total, laparoscopy can be performed in the cirrhotic patient, in the absence of ascites.

\section{Interest of drainage}

The value of intraperitoneal drainage is controversial. The risk of damaging a parietal vein during its placement of the drain and the risk of persistent flow at its removal are advanced. Parietal distension secondary to postoperative ascites can, moreover, be limited by iterative punctures. No comparative study 
has specifically studied the benefits of preventive drainage.

In total, no recommendation can be made regarding the indication for drainage after hernia repair in a cirrhotic patient.

\section{In post-operative}

The rational is the same as that which validates the preoperative control of ascites (see above). The international recommendations available (35) emphasize the need for optimal medical treatment of ascites postoperatively.

In total, control and prevention of ascites is recommended postoperatively.

\section{Place of Alternative Treatments}

\section{Place of the transjugular portosystemic shunt}

The value of TIPS in reducing postoperative complications by reducing the volume of ascites is controversial (36,37). A small series discussed the feasibility and low morbidity of the association TIPS and emergency surgery (38).

\section{Place of the peritoneal-vesical pump}

The management of refractory ascites by peritoneal-vesical pump (Alfapump) allows the reduction of the use of paracentesis $(39,40)$. Its place in the hernia management strategy in cirrhotic patients has not been studied.

In total, the data in the literature do not allow us to recommend the making of a portosystemic shunt by the transjugular route or the use of a peritoneal-vesical pump to decrease the volume of ascites before parietal surgery in cirrhotic patients.

\section{Discussion}

Cirrhosis is a major risk factor for morbidity and mortality after abdominal wall surgery. The elective umbilical hernia cure in a cirrhotic patient is associated with a mortality 4 times higher than in non-cirrhotic patients, mainly by decompensation of postoperative hepatic function, possibly promoted by an infectious complication. The umbilicus is the preferred site for wall hernias in cirrhotic patients. The presence of ascites increases the risk of complication of umbilical hernia: ulceration, rupture or strangulation, and the risk of mortality. In the case of strangulation of $\mathrm{HO}$ in the cirrhotic patient, postoperative mortality is estimated at $10 \%$.

Based on our recommendations, it is possible to discuss in practice the different factors that influence the results of abdominal wall surgery in cirrhotic patients (ascites, cirrhosis stage, surgical technique and urgency). of the intervention) and the daily behaviour.

The increase in abdominal pressure secondary to ascites is responsible for the appearance of the umbilical hernia (20 to $40 \%$ of cirrhotic patients versus $2 \%$ of the general population), as well as the weakening of the muscular wall linked to amyotrophy and undernutrition. Ascites also promotes recurrences after wall repair. Appropriate control of ascites (via diuretics, a sodium diet and repeated paracentesis) improves the results of cirrhotic wall surgery, both in terms of postoperative complications (infection of the operating site) and recurrence. The paracentesis must repeatedly evacuate small amounts of ascites, as the sudden and significant reduction in the volume of ascites can promote hernial strangulation. Before starting the paracentesis, it is desirable to place an abdominal compression (belt or compression bandage) centred on the hernia to prevent the externalization of the digestive tract by the collar of the hernia at the time of the evacuation of ascites. To treat possible refractory ascites, TIPS or peritoneal-vesical dialysis can be used.

The results of surgery in the cirrhotic patient are correlated with the stage of the disease, evaluated by the CHILD and MELD scores. The advantage of MELD is that it uses only objective parameters (serum bilirubin, serum creatinine and INR) and reliably predicts postoperative mortality at D30, D90 
and long term. In addition, mortality from non-hepatic surgery is estimated at $10 \%$ for a CHILD A stage, 30\% for a CHILD B stage and up to $80 \%$ for a C stage (41). These two scores can be used in addition to daily clinical practice and allow collegial discussion with the hepatologist to validate the operative indication in these patients at risk.

One of the major problems with abdominal wall surgery for cirrhotic patients is recurrence, which is favoured by muscle loss and ascites. However, no well-conducted comparative study allows us to know which surgical technique is most appropriate for this type of patient. Likewise, the place of bioprostheses (biosynthetic, slowly absorbable or biological) is not known [42]. Regarding the positioning of the prosthesis, although there is still no consensus, it seems preferable to avoid the intraperitoneal site which seems to increase the risk of infection. To treat an inguinal hernia, it seems preferable to avoid resecting but rather to push back the peritoneal sac to avoid its opening and thus prevent the flow of ascites in contact with prosthetic material. The laparoscopic approach theoretically brings advantages for the cirrhotic. Mainly, the small incisions are less dilapidated and can reduce blood loss, postoperative pain and the flow of ascites by a laparotomy scar. Nevertheless, the risk of haemorrhage in a patient who has an abdominal collateral venous circulation seems unacceptable for laparoscopy. In practice, in case of a vent, we prefer to reject cirrhotic patients whose CHILD stage is higher than A6 or if they have ascites. In a symptomatic patient (pain, episodes of excitement of the incisional hernia), if an incisional hernia treatment is necessary, the prior hepatological treatment must be optimal to dry up the ascites. So, under standard conditions, we use a nonabsorbable prosthesis, placed in retro-muscular site, although the slowly absorbable mesh seem interesting in this situation.

In emergencies, the use of nonabsorbable mesh is not recommended due to the theoretically increased risk of infection. In case of rupture of the navel or strangulated umbilical hernia, surgery must include: treatment of contents of the hernia with possible intestinal resection, complete resection of the peritoneal sac, an omphalectomy because the skin is poorly vascularized at this level, intraperitoneal drainage preventing postoperative abdominal distension linked to possible hepatic decompensation, transverse aponeurotic suture overcoat with slowly absorbable single-strand thread (the nonabsorbable thread can become infected and does not reduce the risk of recurrence) and an airtight skin suture with continuous overlock.

\section{Conclusion}

The cirrhotic patient is fragile due to liver disease-induced organ failures. The cirrhosis severity determines the postoperative mortality risk. Abdominal hernias are common in cirrhotic patients. The operative indications for these hernias remain controversial, but intervening electively is preferable to emergency surgery, regardless of Child's score. The recurrences prevention relies on parietal mesh installation, preferably retro-muscular, and ascites intensive treatment.

Laparoscopy should be used with caution, due to the risk of bleeding. No recommendation can be made on the use of prophylactic intra-abdominal drainage. The literature data do not allow the trans-jugular route portosystemic shunt recommendation, nor the use of a peritoneal-vesical pump to decrease the ascites volume before parietal surgery in cirrhotic patients.

\section{Conflict of Interests}

The authors declare no conflict of interests.

\section{References}

1. Shlomovitz E, Quan D, Etemad-Rezai R, McAlister VC. Association of recanalization of the left umbilical vein with umbilical hernia in patients with liver disease. Liver Transplant. 2005;11(10):1298-9.

2. Belghiti J, Durand F. Abdominal wall hernias in the setting of cirrhosis. Semin Liver Dis. 1997;17(3):219-26.

3. Bhangui P, Laurent A, Amathieu R, Azoulay D. Assessment of risk for non-hepatic surgery in cirrhotic patients. J Hepatol. 2012; $57(4): 874-84$. 
4. Cho SW, Bhayani N, Newell P, Cassera MA, Hammill CW, Wolf RF, et al. Umbilical hernia repair in patients with signs of portal hypertension: surgical outcome and predictors of mortality. Arch Surg. 2012;147(9):864-9.

5. Hansen JB, Thulstrup AM, Vilstup H, Sørensen HT. Danish nationwide cohort study of postoperative death in patients with liver cirrhosis undergoing hernia repair. Br J Surg. 2002;89(6):805-6.

6. Oh H-K, Kim H, Ryoo S, Choe EK, Park KJ. Inguinal hernia repair in patients with cirrhosis is not associated with increased risk of complications and recurrence. World J Surg. 2011;35(6):1229-33; discussion 1234.

7. Douard R, Lentschener C, Ozier Y, Dousset B. Operative risks of digestive surgery in cirrhotic patients. Gastroenterol Clin Biol. 2009;33(6-7):555-64.

8. Loriau J, Manaouil D, Mauvais F. [Management of umbilical hernia in cirrhotic patients]. J Chir (Paris). 2002;139(3):135-40.

9. Hurst RD, Butler BN, Soybel DI, Wright HK. Management of groin hernias in patients with ascites. Ann Surg. 1992;216(6):696-700.

10. Carbonell AM, Wolfe LG, DeMaria EJ. Poor outcomes in cirrhosisassociated hernia repair: a nationwide cohort study of 32,033 patients. Hernia. 2005;9(4):353-7.

11. Marsman HA, Heisterkamp J, Halm JA, Tilanus HW, Metselaar HJ, Kazemier G. Management in patients with liver cirrhosis and an umbilical hernia. Surgery. 2007;142(3):372-5.

12. Patti R, Almasio PL, Buscemi S, Famà F, Craxì A, Di Vita G. Inguinal hernioplasty improves the quality of life in patients with cirrhosis. Am J Surg. 2008;196(3):373-8.

13. Saleh F, Okrainec A, Cleary SP, Jackson TD. Management of umbilical hernias in patients with ascites: development of a nomogram to predict mortality. Am J Surg. 2015;209(2):302-7.

14. Ecker BL, Bartlett EK, Hoffman RL, Karakousis GC, Roses RE, Morris JB, et al. Hernia repair in the presence of ascites. J Surg Res. 2014;190(2):471-7.

15. Andraus W, Pinheiro RS, Lai Q, Haddad LBP, Nacif LS, D'Albuquerque LAC, et al. Abdominal wall hernia in cirrhotic patients: emergency surgery results in higher morbidity and mortality. BMC Surg. 2015;15:65.

16. Eker HH1, van Ramshorst GH, de Goede B, Tilanus HW, Metselaar $\mathrm{HJ}$, de Man RA, Lange JF, Kazemier G. A prospective study on elective umbilical hernia repair in patients with liver cirrhosis and ascites. Surgery. 2011;150(3):542-6.

17. Gray SH, Vick CC, Graham LA, Finan KR, Neumayer LA, Hawn MT. Umbilical herniorrhapy in cirrhosis: improved outcomes with elective repair. J Gastrointest Surg. 2008;12(4):675-81.

18. Choi SB, Hong KD, Lee JS, Han HJ, Kim WB, Song TJ, et al. Management of umbilical hernia complicated with liver cirrhosis: an advocate of early and elective herniorrhaphy. Dig Liver Dis. 2011;43(12):991-5.

19. O'Hara ET, Oliai A, Patek AJ, Nabseth DC. Management of umbilical hernias associated with hepatic cirrhosis and ascites. Ann Surg. 1975;181(1):85-7.

20. Hassan AMA, Salama AF, Hamdy H, Elsebae MM, Abdelaziz AM, Elzayat WA. Outcome of sublay mesh repair in non-complicated umbilical hernia with liver cirrhosis and ascites. Int J Surg. 2014; 12(2):181-5.

21. Park JK, Lee SH, Yoon WJ, Lee JK, Park SC, Park BJ, et al. Evaluation of hernia repair operation in Child-Turcotte-Pugh class $C$ cirrhosis and refractory ascites. J Gastroenterol Hepatol. 2007; 22(3):377-82.

22. Belghiti J, Desgrandchamps F, Farges 0 , Fékété F. Herniorrhaphy and concomitant peritoneovenous shunting in cirrhotic patients with umbilical hernia. World J Surg. 1990;14(2):242-6.

23. Leonetti JP, Aranha GV, Wilkinson WA, Stanley M, Greenlee HB.
Umbilical herniorrhaphy in cirrhotic patients. Arch Surg. 1984; 119(4):442-5.

24. Runyon BA, Juler GL. Natural history of repaired umbilical hernias in patients with and without ascites. Am J Gastroenterol. 1985; 80(1):38-9.

25. McKay A, Dixon E, Bathe 0 , Sutherland F. Umbilical hernia repair in the presence of cirrhosis and ascites: results of a survey and review of the literature. Hernia. 2009;13(5):461-8.

26. Fink C, Baumann P, Wente MN, Knebel P, Bruckner T, Ulrich A, et al. Incisional hernia rate 3 years after midline laparotomy. $\mathrm{Br} \mathrm{J}$ Surg. 2014;101(2):51-4.

27. Kanters AE, Krpata DM, Blatnik JA, Novitsky YM, Rosen MJ. Modified hernia grading scale to stratify surgical site occurrence after open ventral hernia repairs. J Am Coll Surg. 2012;215(6): 787-93.

28. Runyon BA, Juler GL. Natural history of repaired umbilical hernias in patients with and without ascites. Am J Gastroenterol. 1985; 80(1):38-9.

29. Belli G, D’Agostino A, Fantini C, Cioffi L, Belli A, Russolillo N, et al. Laparoscopic incisional and umbilical hernia repair in cirrhotic patients. Surg Laparosc Endosc Percutan Tech. 2006; 16(5):330-3.

30. Yu BC, Chung M, Lee $G$. The repair of umbilical hernia in cirrhotic patients: 18 consecutive case series in a single institute. Ann Surg Treat Res. 2015;89(2):87-91.

31. Ammar SA. Management of complicated umbilical hernias in cirrhotic patients using permanent mesh: randomized clinical trial. Hernia J Hernias Abdom Wall Surg. 2010;14(1):35-8.

32. Cobb WS, Heniford BT, Burns JM, Carbonell AM, Matthews BD, Kercher KW. Cirrhosis is not a contraindication to laparoscopic surgery. Surg Endosc. 2005;19(3):418-23.

33. Sarit C, Eliezer A, Mizrahi S. Minimally invasive repair of recurrent strangulated umbilical hernia in cirrhotic patient with refractory ascites. Liver Transplant. 2003;9(6):621-2.

34. Juo $Y-Y$, Skancke M, Holzmacher J, Amdur RL, Lin PP, Vaziri K. Laparoscopic versus open ventral hernia repair in patients with chronic liver disease. Surg Endosc. 2017;31(2):769-77.

35. Runyon $B$ a. AASLD PRACTICE GUIDELINE Management of Adult Patients with Ascites Due to Cirrhosis: Update 2012. Hepatology. 2013;57(4):1651-3.

36. Telem DA, Schiano T, Divino CM. Complicated hernia presentation in patients with advanced cirrhosis and refractory ascites: management and outcome. Surgery. 2010;148(3):538-43.

37. Chatzizacharias NA, Bradley JA, Harper S, Butler A, Jah A, Huguet $E$, et al. Successful surgical management of ruptured umbilical hernias in cirrhotic patients. World J Gastroenterol. 2015;21(10): 3109-13.

38. Fagan SP, Awad SS, Berger DH. Management of complicated umbilical hernias in patients with end-stage liver disease and refractory ascites. Surgery. 2004;135(6):679-82.

39. Solà E, Sanchez-Cabús S, Rodriguez E, Elia C, Cela R, Moreira R, et al. Effects of alfapumpTM system on kidney and circulatory function in patients with cirrhosis and refractory ascites. Liver Transplant. 2017;23(5):583-93.

40. Thomas MN, Sauter GH, Gerbes AL, Stangl M, Schiergens TS, Angele $\mathrm{M}$, et al. Automated low flow pump system for the treatment of refractory ascites: a single-center experience. Langenbecks Arch Surg. 2015;400(8):979-83

41. Banu P, Socea B, Carâp A, Motofei I, Balalau C, Bobic S, et al. The Current Surgical Managemnt of the Parietal Deffects in Patients with Liver Cirrhosis - Options and Limits. Our Experience and Review of Literature. Chirurgia (Bucur). 2019;114(1):29-38.

42. Moszkowicz D, Bouillot JL. Biological mesh: From concept to clinical reality. J Visc Surg. 2018;155(5):347-348. 